\title{
The use of a geographic information system to study geotechnical problems in urban areas
}

\author{
Abdellah AZOUGAY ${ }^{1,{ }^{*}}$, Halima REZQI $^{1}$, and Mostafa OUJIDI ${ }^{1}$ \\ ${ }^{1}$ Laboratoire de Géosciences Appliquées, Département de Géologie, Faculté des Sciences, Université Mohamed Premier, BP524, 60000 \\ Oujda, Maroc.
}

Abstract. Bad choice of construction site or poor number or local geotechnical study test lead to construction ruin; hence the need to have a geotechnical map for each urban area, which will constitute a reference for urban planners. Urban geotechnics is the study of urban land environments to provide a scientific and technical database for rational urban development and land use planning. The aim of this work is to make an inventory of all potential geotechnical problems in the soil bounded by the urban perimeter of Beni Ensar city. So to characterize the soil many geotechnical tests carried out in the laboratory and in situ are analysed. The results of these geotechnical tests are represented geo-spatially using GIS software. The thematic maps obtained will constitute a reference to the planners and the various actors in this field to adapt development plans and types of buildings to the properties of the supporting soil. They will also allow the civil engineering laboratory to optimize the choice of the study method and the types of tests.

\section{Introduction}

The strategic management of the city's soil has become such an interesting issue in recent years that a new interdisciplinary field has been created under the name "Urban Geosciences". This new field focuses on urban geo-environments; it can be defined as the study of land resources and geotechnical risks related to the development, redevelopment and expansion of urban areas, in order to provide geotechnical knowledge to planners and politicians for rational urban planning and development. Following this approach, several researchers have studied the urban geotechnics of some cities [1]-[7].

The majority of construction problems in urban areas are directly or indirectly related to geological, geotechnical and hydrogeological conditions. For example, the problem of differential settlement that directly affects buildings is related to geological or geotechnical conditions [8]-[11].

The Beni Ensar city is built on recent heterogeneous sedimentary deposits of quaternary age, and of very variable thickness. A sandy layer on the Mediterranean side, a near-surface water table level and considerable seismic activity make the site suitable for seismic wave amplification and liquefaction. The soil surrounding the Marchica Lagoon is composed of heterogeneous clay with mechanical properties that vary considerably by location, causing damage to buildings.

The objective of this work is to participate in urban development and relevant planning, using geological and geotechnical data in the characterization, modeling and detection of geotechnical problems that may occur. The acquisition, processing and analysis of geological and geotechnical data will allow us to study the geoenvironment of Beni Ensar city, and to propose a map of suitability for urban planning.

\section{Location and geological context of the study area}

Beni Ensar or Beni Ansar, or Aït Nsar is a port city, with an area of $43 \mathrm{~km}^{2}$, located in the northeast of Morocco. It is bounded to the north by the Mediterranean Sea, to the south by the Gourougou massif, to the west by the landlocked city of Melilla and to the east by the lagoon of Marchica.

The lagoon of Marchica is among the largest lagoons in the southern Mediterranean, it is semi-oval in shape, with a length of about $25 \mathrm{~km}$ and a wide width of $7 \mathrm{~km}$, the maximum depth of the lagoon is $8 \mathrm{~m}$, and its surface area is $115 \mathrm{~km}^{2}$, it is the largest lagoon in Morocco.

During the geotechnical surveys carried out in the study area, the existence of a groundwater table was noted, the depth of this groundwater table is variable along the city, it is $-1 \mathrm{~m}$ from the level of the natural ground in the vicinity of the Marchica lagoon, moving away from the coast the depth of the groundwater table increases to disappear at the level of the surveys carried out at Monte Gourougou.

The Beni Ensar city is crossed by small rivers, the hydrographic network is torrential; these creeks are dry all year round and only work during periods of precipitation. Four creeks were identified by $\mathrm{N}$. AMARJOUF: Arroyo La Mezquita, Ouchen, Akhandouk and chaâbat Akhandouk [12].

Arroyo la Mezquita creek: It takes its source from the Gourougou massif and crosses the city of Melilla to flow directly into the Beni Ensar harbor, to constitute a geographical border between the two cities of Beni Ensar and Melilla. The surface area of its watershed is around $11.43 \mathrm{Km}^{2}$.

Ouchen creek: Also known as Arroyo Del Lobo (according to Spanish maps). It also has its source in the 
Gourougou massif. It crosses the Beni Ensar city in a densely populated area, causing major flooding on rainy days. Before the construction of the Beni Ensar harbor on the marshy part of Marchica lagoon in 1978, Ouchen creek led directly into the lagoon of Marchica, but following the filling of the marshy part, this creek is now without an outlet to the sea.

Akhandouk creek drains the rainwater that has fallen over an area of $4.5 \mathrm{~km}^{2}$ on Mount Gourougou. It crosses the Ihamoutienne district downstream and the railway, before flowing into the Marchica lagoon. It is currently limited by concrete walls at the floodplain.

Chaâbat Akhandouk: It takes its source from the douar Ipijutane with a very slight slope. It has a watershed area of less than $1 \mathrm{Km}^{2}$. It leads directly into the Marchica lagoon.

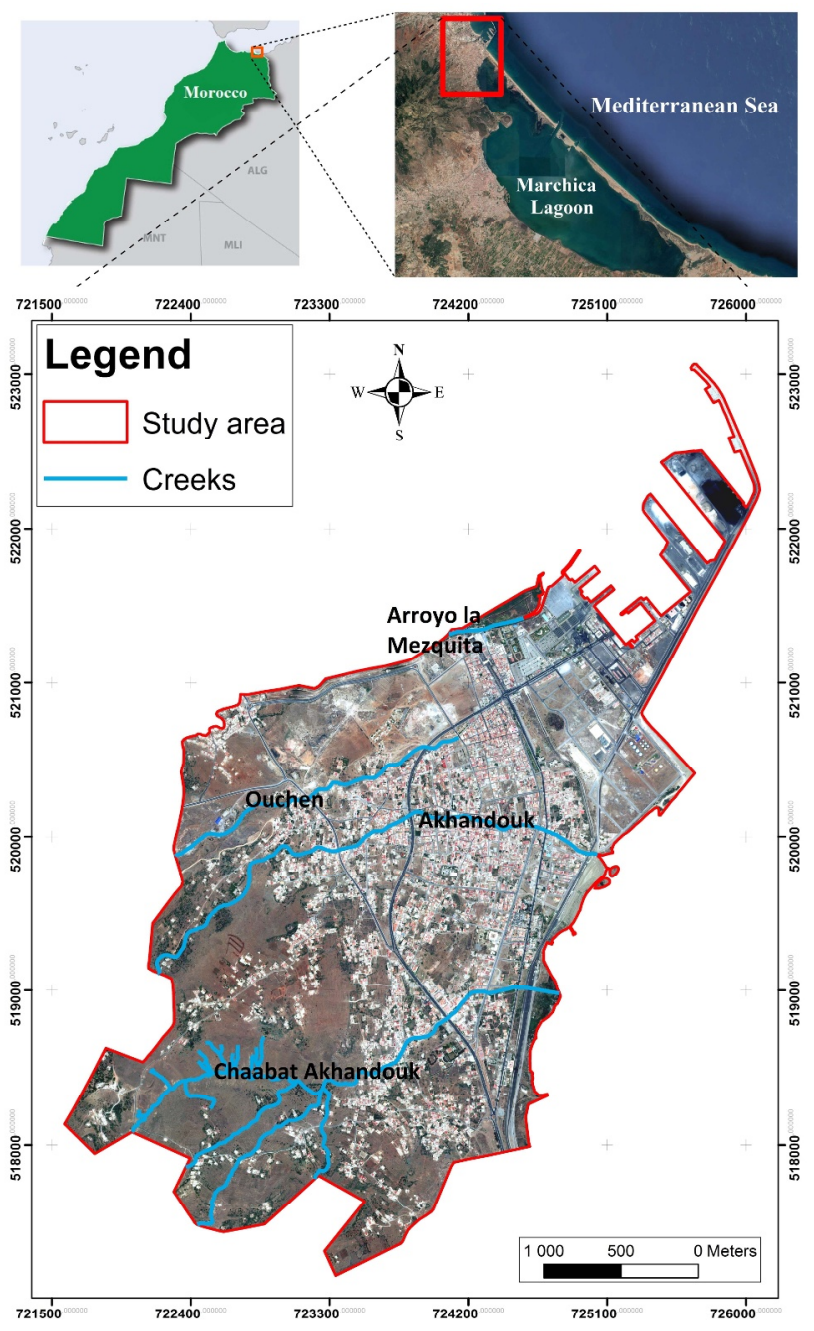

Fig. 1. Location of the study area

Around the city of Beni Ensar, three geological units can be distinguished:

- The Gourougou massif is located in the NW of the lagoon and reaches a peak of $887 \mathrm{~m}$. It is a complex stratovolcano with a diameter of $15 \mathrm{~km}$ in the N-S direction and $25 \mathrm{~km}$ in the $\mathrm{E}-\mathrm{W}$ direction, formed by different volcanic rocks: Latites, which occupy the largest surface area of this massif, basalt, absarokites, andesites, shoshonites, ashes (tufs) and pyroclastites [13] ; this massif is composed of three volcanic units Miocene and Pliocene: calcoalkaline (9 to $6.6 \mathrm{Ma}$ ), shoshonitic ( 7 to $5.4 \mathrm{Ma}$ ) and alkaline (4.7 to $2.6 \mathrm{Ma}$ ) [14]. The alteration of these volcanic rocks has given the soil on which a large part of the city of Beni Ensar is built, and which can reach significant thicknesses in flat areas.

- Between the lagoon of Marchica and the sea, a rectilinear barrier beach, $25 \mathrm{~km}$ long and variable in width between 0.3 and $1.5 \mathrm{~km}$, emerges. This sandy barrier, built by predominantly north to northeast winds, is formed by a consolidated dune network that forms the backbone of the lido [15]. In its northwestern part there are shell sands covered locally by current dunes, while in the southeastern part there are dune calcarenites with more or less deep brown soils [16]. This transgressive barrier island system [17] is cut off by a new pass that connects the Mediterranean Sea to the lagoon and whose location has varied over time.

- The subsidised plain of Bou Areg receives the erosion products from the mountain ranges that surround it. The filling material is of a colluvial nature, it increases in thickness from upstream to downstream where it exceeds $60 \mathrm{~m} \mathrm{[18].}$

\section{Data and methodologies}

The first step in initiating any urban geotechnical mapping operation is to delineate the study area, then collect and explore available data for the study area; this includes the nature of the surface formations, seismotectonic overview, topography, geotechnical properties of the materials, and the conduct of geotechnical tests.

Geotechnical boreholes have a set of information including the most relevant properties: thickness of the different layers, Atterberg consistency limits (natural water content, plasticity limit, liquidity limit, and plasticity index), oedometrique test or consolidation tests (initial void ratio, effective overload pressure $\left(\sigma v^{\prime}\right)$, preconsolidation pressure $\left(\sigma p^{\prime}\right)$, and compression index (Cc)).

Based on geotechnical boreholes (Fig.2), and all the data collected, the first step is the calibration and digitization of the various maps, then the implementation of geotechnical surveys and the construction of a geotechnical database by adopting a procedure developed to more reliably predict spatial geotechnical information, this database will allow users to study geotechnical data referenced by projected coordinates that can be easily exported to other software. 


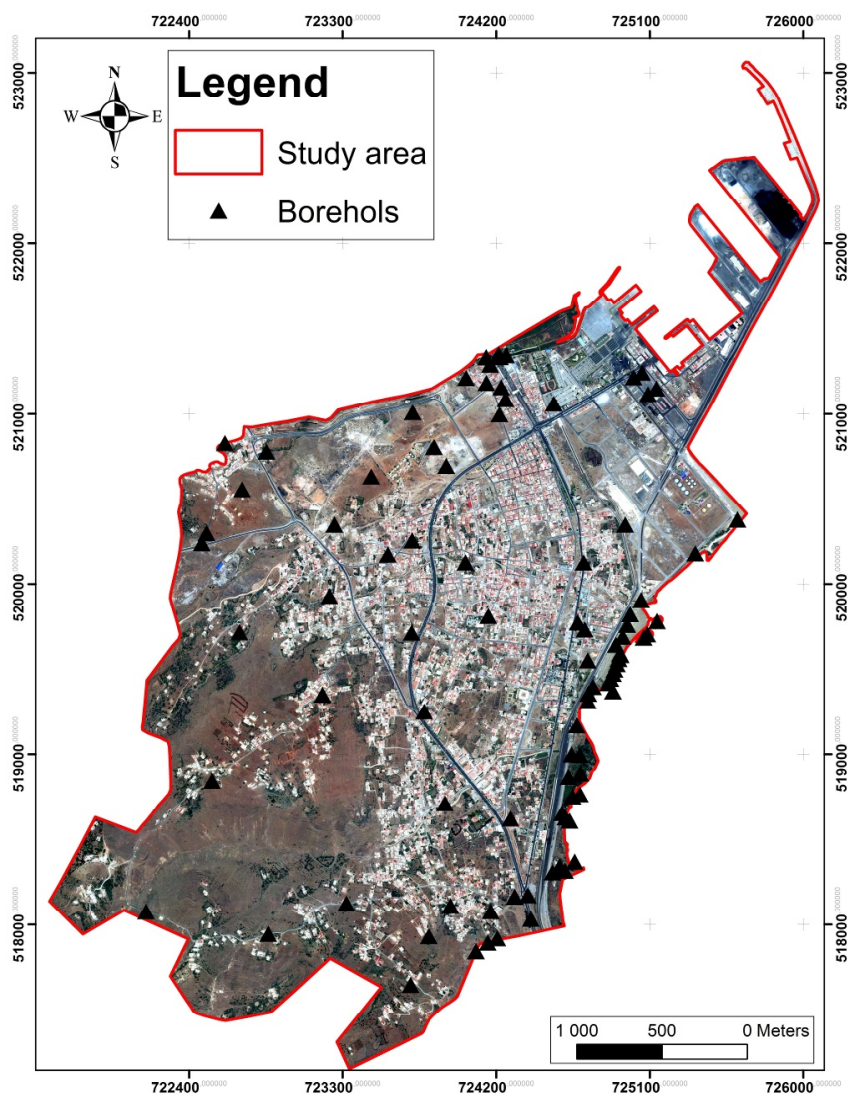

Fig. 2. Boreholes location

After processing and analysis of the geotechnical database, the results can be used in:

- Geological study based on geological maps;

- The study of the topography of the study area from topographic maps and digital terrain models;

- The realization of a geotechnical map based on a correlation between the different lithological profiles extracted from geotechnical boreholes;

- The realization of slop map;

- Study of susceptibility to settlement and liquefaction.

\section{Results}

\subsection{Topography of the study area}

Geomorphology is a very useful means for the explanation and interpretation of current lithology, and its development over time, so it is an essential element of geotechnical mapping. The geological history of the Beni Ensar area has been shaped by volcanic, sedimentary and tectonic events that have influenced the current morphology of the study area.

The Beni Ensar city is characterized by a varied morphology, composed of two main morphological elements, namely the Gourougou Mountains and the plain on which most of the city is based.

The topographic maps with1:50,000 scale do not cover all study area, so for the creation of the Digital Elevation Model (DEM), based on Lambert's conformal conical projection, Clarke's Ellipsoid 1880, Merchich's Datum; a combination of topographic maps and altimetric data downloaded from the Alaska Satellite Facility web site (www.asf.alaska.edu) was used to provide a good DEM quality, with a resolution of $13 \mathrm{~m}^{*} 13 \mathrm{~m}$ (Fig. 3).

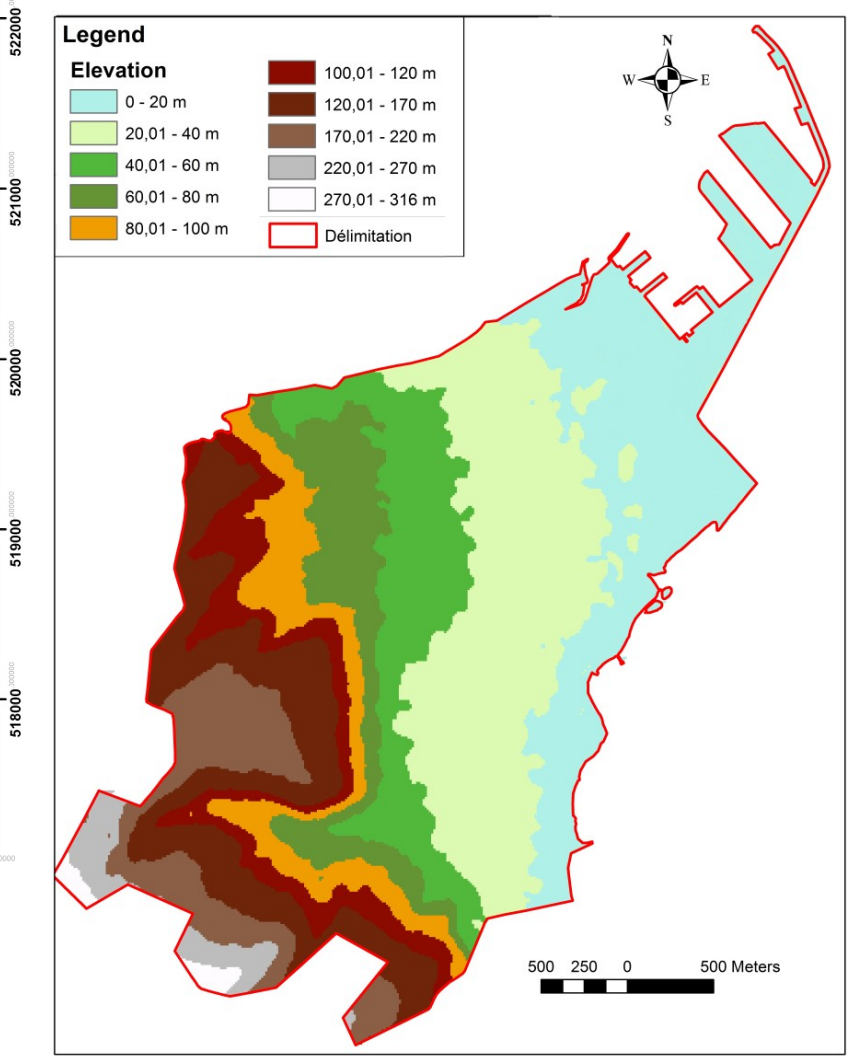

Fig. 3. The digital elevation model of the study area

The highest point in the study area, at an altitude of 316 meters, is located in the Gourougou mountain, which is an ancient volcano, at the foot of this mountain, the terrain is relatively flat up to the Mediterranean coast on the northern side, and up to the Marchica lagoon in the east.

\subsection{Lithology and soil layer}

The lithology of the study area is determined based on the geological map of the area and 116 geotechnical boreholes of different depths covering the entire city of Beni Ensar; from these boreholes, samples of intact or altered soils were extracted to identify and classify the different lithological formations recognized in the field. The first step of this work is to collect the results of geotechnical boreholes of different depths with their projected coordinates, the entire study area is covered by these boreholes, for each borehole a lithological section is prepared, these boreholes are then implemented on the ArcGIS geographic information systems management software. In order to carry out geotechnical mapping of the study area, it is essential to identify and classify the different soil layers, granulometric tests and tests to determine the Atterberg limits have been carried out to classify the soils according to the Unified Soil Classification System (USCS). 
For the creation of a geotechnical database, a compilation of the information contained in the boreholes, the results of the identification tests and the results of the soil classification is done on GIS software, which will allow us a good geo-spatial representation and a better readability of the data.

The facies or soil class represented on the map is the one that is dominant and closest to the surface, on which the foundations of the buildings can rest. On most geotechnical boreholes there is often a layer of backfill or topsoil that is not taken into account in our work. In order to establish the limits of the different formations, a correlation between the dominant soil classes is made.

As a result, we have distinguished 6 geotechnical formations. On the boreholes located to the south and southwest of the Beni Ensar city we noticed the dominance of volcanic rocks on the lithological sections of this area, which can reach $30 \mathrm{~m}$, we were unable to determine the lower limit of this formation. The second formation is gravel composed of more than $50 \%$ of elements that have a diameter greater than $2 \mathrm{~mm}$, according to the USCS classification this layer is composed of silty gravel or clayey gravel, to make the map easier we have named these two classes as gravel. The third formation is a low or high plastic silt layer that we have joined as a silt layer. Clay also occupies part of the city's lithology, there are two types of clay; low plastic clay is interspersed between silts and high plastic clays that are located in some areas surrounding the lagoon of Marchica, such as the city's cornice. The last formation is the sand, it occupies the coastal part of the city and the port area; these sands are of marine origin due to their shell richness.

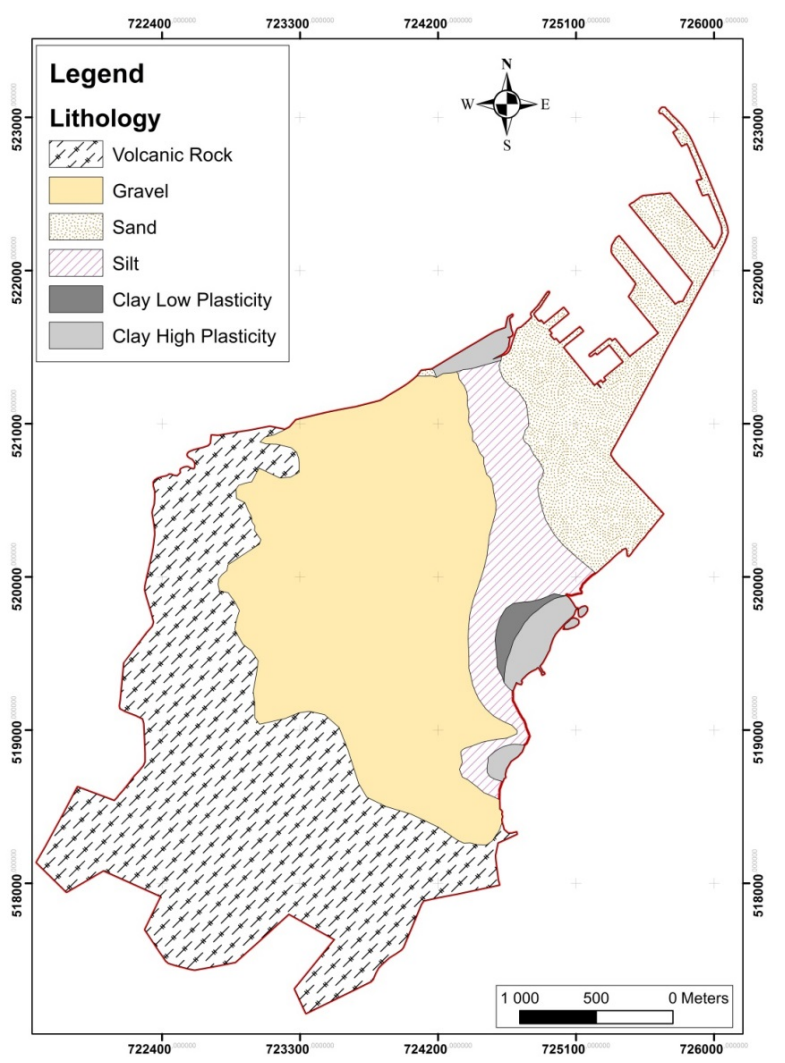

Fig. 4. Lithological map of Beni Ensar city

\subsection{Liquefaction susceptibility layer}

The Alboran Sea, which is a seismically active area known for the propagation of transverse faults, is located near our study area; this seismic activity is due to the dexterous converging displacement between the African and Eurasian plates and is of the order of $5 \mathrm{~mm} / \mathrm{year}$ in the NW-SE direction [19]. Then there may be a risk of liquefaction in our area.

In this part we will study the susceptibility of the soil to liquefaction, the soils most sensitive to liquefaction are non-coherent (powdery) soils, non-powdery (coherent) soils liquefy under special conditions only [20]. Researchers in this field have given several criteria for determining susceptibility to liquefaction; in this study we will use the criteria of [21]. Kramer chose four criteria:

- Historical criteria;

- Geologic criteria;

- Compositional criteria;

- State criteria.

The seismic history of the area can provide valuable information that can inform us about the risk of liquefaction, soils that have undergone liquefaction can be subjected to it in future earthquakes, to our knowledge and we consult the bibliography, the study area has not undergone any liquefaction phenomenon in the past.

Sediment transport and sedimentation processes can give an idea of susceptibility to liquefaction, the transport which gives us sedimentation by layers formed by particles of almost the same diameter in a saturated environment, can give layers of soil that can liquefy.

The compositional criterion is also important, when the soil is formed by particles of different sizes, the small particles settle during sedimentation between the large particles, thereby reducing the decrease in soil volume, and the development of pore pressure in an earthquake. The shape of the particles also has an effect; the layers formed by angular particles are less susceptible to liquefaction, because of their high resistance to friction. When density is fixed, the state of effective stress in the soil gives us an idea of the susceptibility to liquefaction; high effective stress soils are less susceptible to liquefaction, since the liquefaction phenomenon occurs when this stress is equal to or close to zero.

Based on these four criteria, it can be said that the coastal area of the port and dune barrier separating the Marchica lagoon from the Mediterranean Sea is susceptible to liquefaction due to the presence of sand and the groundwater near the surface, as well as the verification of Kramer's geological and compositional criteria. 


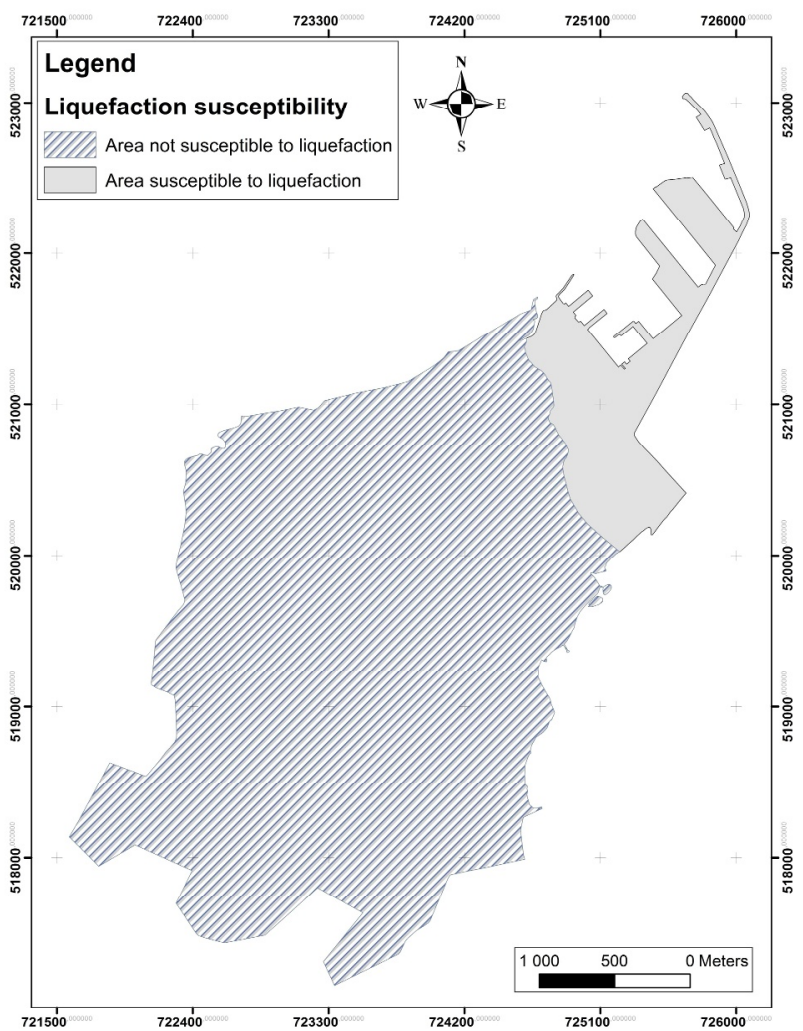

Fig. 5. Liquefaction susceptibility map

\subsection{Slope layer}

Slope is a very important factor when it comes to landslide risk; the study area has experienced slope stability problems over time due to civil engineering work. Based on the DEM already produced, a map of the slopes is made, the slopes are represented in degrees; two classes of slopes are represented on the map (Fig. 6), the low and medium slopes are in white, and the high slopes are in grey.

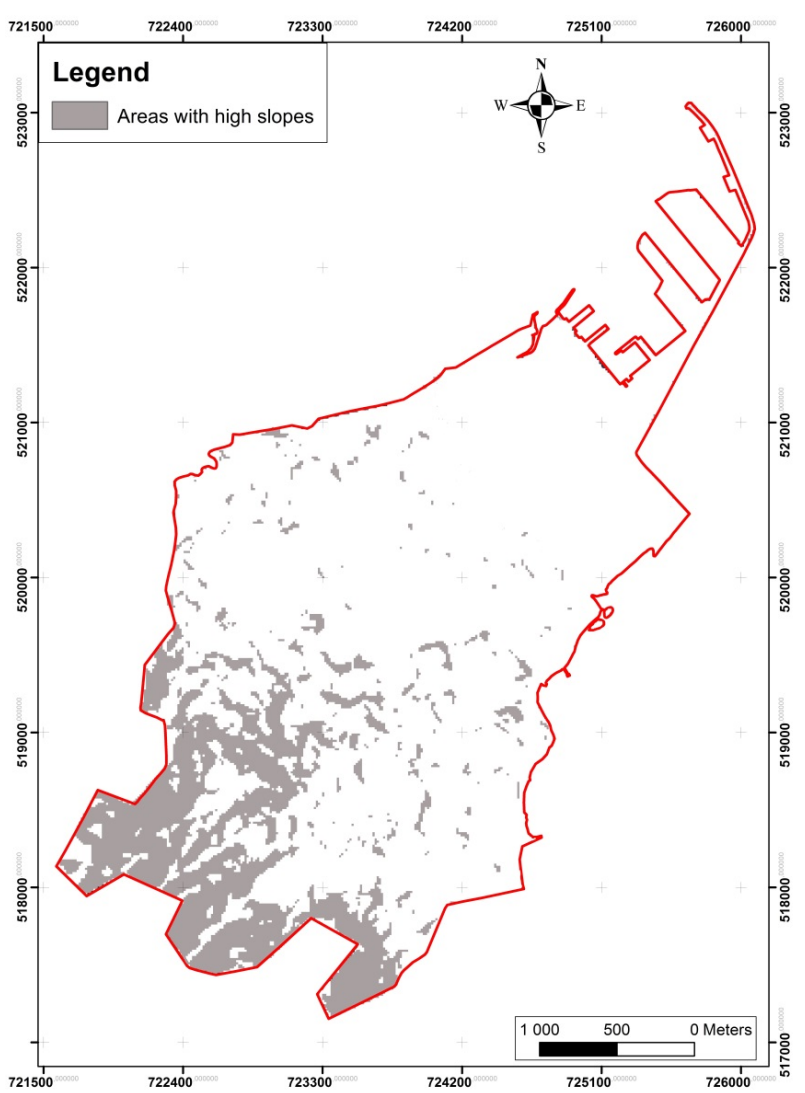

Fig. 6. Slopes map

It should be noted that most of the steeply sloping areas are located to the south and southwest of the city of Beni Ensar, this area is formed by volcanic rocks that outcrop or are covered by a thin layer of clay matrix gravel, the upper part of the volcanic base is always altered and fractured, which makes the risk of mobilization of these upper layers strong, hence the need to study this complex phenomenon before civil engineering projects and especially road projects are implemented.

\subsection{Consolidation and compressibility potentials}

For the determination of the soil consolidation state we are led to make a comparison between the preconsolidation stress $\sigma_{p}^{\prime}$ of the soil and the effective vertical stress $\sigma^{\prime}{ }_{\mathrm{v} 0}$, the calculation of $\sigma_{\mathrm{v} 0}^{\prime}$ requires the determination of the soil density by a test, the preconsolidation stress $\sigma_{\mathrm{p}}$ is determined by the oedometric test, by comparing these two constraints, we can say that the soil is under consolidated $\left(\sigma_{\mathrm{v} 0}^{\prime}>\sigma_{\mathrm{p}}^{\prime}\right)$, normally consolidated $\left(\sigma_{\mathrm{v} 0}^{\prime} \approx \sigma_{\mathrm{p}}^{\prime}\right)$ or over-consolidated $\left(\sigma_{\mathrm{v} 0}^{\prime}<\right.$ $\sigma_{\mathrm{p}}$ ), in doing the necessary tests on the sol, we find that they are in a normally consolidated state.

The compressibility potential can also be determined by an index obtained from the oedometric test which is called the soil compression index $\mathrm{Cc}$, when the $\mathrm{Cc}$ is high, the resulting deformation of the same stress change will be important. The soils most likely to be compressible are fine soils, in the study area there are silts and clays that belong to this type of soil. The silt 
layer has a compression index that varies between 0.1 and 0.2 which allows us to say that this layer is moderately compressible, the low plastic clay layer has a Cc between 0.2 and 0.3 which indicates a fairly high compressibility, the last layer is the most compressible, it has a $\mathrm{Cc}$ between 0.3 and 0.4 so it is classified as highly compressible.

\section{Discussions}

In the literature, there are many cases that address urban geotechnical mapping of big cities [1]-[4], [7], but few of them deal with the case of small cities such as Beni Ensar, this port city has the necessary assets to develop and be a big strategic city in eastern Morocco, with a large urban extension, hence the need to prepare maps for planners and urban planners that show geotechnical zoning is the possible geotechnical problematics.

This study is based on the creation of a geographical geotechnical information system; the information from the boreholes and geotechnical tests has been transferred geospatially to the GIS software to facilitate the control and use of the data, and also to facilitate the representation of the results. In this work we have integrated almost all the problems that can affect buildings or other infrastructure in one single geotechnical database, which will provide greater flexibility and visibility.

The preparation of the basic documents is done in such a way as to collect as much data as possible, and to choose the highest quality from them, or to combine data sources to obtain the best result, as in the case of the MNT. The quality of our results also depends on the geographical coverage of our study area, to have a result that represents the entire area.

The lithology of the city of Beni Ensar is very varied, there are volcanic magmatic rocks and sedimentary deposits of quaternary age, there are consolidated rocks and loose rocks, volcanic rocks are due to the cooling of magma, following a series of volcanic eruptions, the weathering product of these volcanic rocks is transported either by gravity or by water to form the quaternary fill on which the large part of the city of Beni Ensar is built; the coastal part of the city has been dominated by sands transported by the sea.

The study area is a coastal area where the groundwater level is very close to the surface in some areas, and which is located in the vicinity of the Alboran Sea where there are very active faults, so we have all the evidence that the area can be subject to liquefaction, this assumption is confirmed by using the Kramer criteria method.

The state of soil consolidation can provide us with information on the history of stresses in the soil, and give us an idea of its capacity to withstand loads without deformations exceeding the permissible limits.

In this work, we have been able to give as much visibility as possible to the decision-makers through the realization of a suitability map for urban planning (Fig. 7) that takes into account the results of the soil survey of the town of Beni Ensar and the exposure of as many geotechnical problems as possible, such as liquefaction susceptibility, slope layer, consolidation and compressibility potentials.

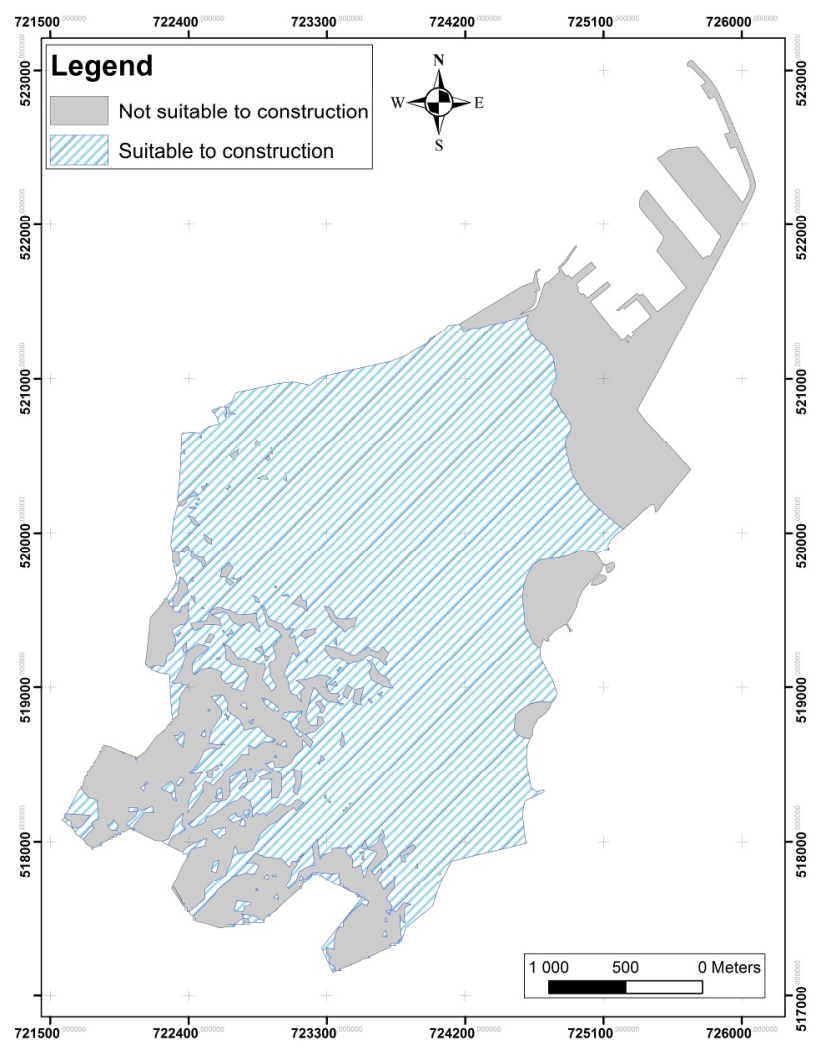

Fig. 7. Suitability to construction considering liquefaction susceptibility, slope layer, consolidation and compressibility potentials

\section{Conclusion}

This work attempts to highlight the importance of the use of the geographic information system in the acquisition, processing, analysis, and representation of results in the field of urban mapping; the use of GIS has allowed us to digitize several documents, build a geotechnical database by compiling the information contained in the geotechnical reports, and construct several layers such as: delimitation of the study area, satellite image, digital elevation model, borehole layout, lithological map, and slope map. The GIS tool also allows us to update the database and results at any time, to produce updated results of this study in the form of different maps.

The southern and southwestern zone is the highest and most rugged area of the city of Beni Ensar, where volcanic rocks dominate; the northern part is the area surrounding the port is based on sand, this sandy area is classified as an area susceptible to liquefaction; the southeastern zone adjacent to the Marchica lagoon is known to contain low and very plastic clays, the risk of compressibility of these layers is very high.

An urban mapping of lithology and the various geotechnical problems that can affect the civil engineering project and cause delays in execution will make it possible to guarantee a very effective tool for the 
rational and sustainable development of this port city. The result of this work will allow non-geological decision-makers to see the importance of geology in urban planning. However, the results of this study do not in any way replace the specific studies that must be carried out during the technical study of civil engineering projects.

\section{References}

[1] S. W. Edbrooke, C. Mazengarb, and W. Stephenson, "Geology and geological hazards of the Auckland urban area, New Zealand," Quat. Int., vol. 103, pp. 3-21, 2003.

[2] R. J. Haworth, "The shaping of Sydney by its urban geology," Quat. Int., vol. 103, pp. 41-55, 2003.

[3] J. F. Nott, "The urban geology of Darwin, Australia," Quat. Int., vol. 103, pp. 83-90, 2003.

[4] E. C. Willey, "Urban geology of the Toowoomba conurbation, SE Queensland, Australia.," Quat. Int., vol. 103, pp. 57-74, 2003.

[5] A. Özsan, A. Öcal, M. Akın, and H. Başarır, "Engineering geological appraisal of the Sulakyurt dam site, Turkey," Bull. Eng. Geol. Environ., vol. 66, pp. 483-492, 2007.

[6] M. El May, J. Kacem, and M. Dlala, "Liquefaction susceptibility mapping using geotechnical laboratory tests," Int. J. Environ. Sci. Technol., vol. 6, no. 2, pp. 299-308, 2009.

[7] M. El May, M. Dlala, and I. Chenini, "Urban geological mapping: Geotechnical data analysis for rational development planning," Eng. Geol., vol. 116, pp. 129-138, 2010.

[8] M. Chrétien, R. Fabre, A. Denis, and A. Marache, "Recherche des paramètres d'identification géotechnique optimaux pour une classification des sols sensibles au retraitgonflement," Rev. Française Géotechnique, vol. 120-121, pp. 91-106, 2007.

[9] D. Breysse, H. Niandou, S. . Elachachi, and L. Houy, "A generic approach to soil-structure interaction considering the effects of soil heterogeneity," Géotechnique, vol. 55, no. 2, pp. 143-150, 2005.

[10] G. . Fenton and D. . Griffiths, "Probabilistic foundation settlement on spatially random soil," J. Geotech. Geoenvironmental Eng., vol. 128, no. 5, pp. 381-390, 2002.

[11] M. . Boscardin and E. . Cording, "Building response to excavation-induced settlement," $J$. Geotech. Geoenvironmental Eng., vol. 115, no. 1, pp. 1-21, 1989.

[12] N. AMARJOUF, "Interactions entre cruesruissellements et aménagements de territoire et leurs impacts sur les versants Nord de la péninsule de Guelâaya : Cas de la baie de Melilla Béni Ansar et la baie de Betoya (Maroc Nord Oriental)," Université Mohammed Premier, 2018.
[13] J. Hernandez, "Le volcanisme miocène du Rif oriental (Maroc): Géologie, pétrologie et minéralogie d'une province shoshonitique," Paris VI, 1983.

[14] M. El Azzouzi, J. Bernard-Griffiths, H. Bellon, R. C. Maury, A. Piqué, S. Fourcade, J. Cotten, and J. Hernandez, "Évolution des sources du volcanisme marocain au cours du Néogène," $C$. R. Acad. Sci. Ser. IIA Earth Planet. Sci, vol. 329, pp. 95-102, 1999.

[15] R. Mahjoubi, "Nature et origine du flux de matière particulaire et son enregistrement dans un milieu paralique microtidal : cas de la lagune de Nador (Maroc nord oriental)," Université Moulay Ismail, Meknes, 2001.

[16] R. Mahjoubi, S. Kamel, B. El Moumni, Y. Noack, and C. Parron, "Nature, Origine et répartition de la phase argiles de la Lagune de Nador (Maroc Nord Oriental)," Geol. Belgica, vol. 6, no. 1-2, pp. 31-42, 2003.

[17] Z. Irzi, "Les environnements du littoral méditerranéen oriental du Maroc compris entre l'oued Kiss et le Cap des Trois Fourches; Dynamique sédimentaire et étude d'impact des sites aménagés et l'analyse des associations de foraminifères benthiques de la lagune de N," Univ. Oujda, 2002.

[18] M. Guillemin and R. Wernli, "Le sondage de Kariet Arekmane et le Néogène du bassin de Nador (Maroc Nord Oriental)," Notes du Serv. géologique du Maroc, vol. 43, no. 321, pp. 255262, 1987.

[19] J. Galindo-Zaldívar, "La tectónica reciente y activa de la región de Al Hoceima (Cordillera del Rif)," in La sismicité de la région d'Al Hoceima: évaluation des aléas et de la vulnérabilité, 2016, p. 56.

[20] K. Kumar, BASIC GEOTECHNICAL EARTHQUAKE ENGINEERING. New Delhi: New age international publishers, 2008.

[21] S. L. Kramer, Geotechnical Earthquake Engineering. Prentice Hall, 1996. 